\title{
Collusion-Conflict Abuses and Meng Wanzhou's Extradition Case
}

Sean D. Yates"

The author is an English Barrister, General Counsel of China State Construction Engineering Corporation (Middle East) L.L.C. and undertaking PhD research on new international commercial courts and their domestic relations.

DOI: $\underline{10.36348 / \text { sijlcj.2020.v03i11.014 }}$

| Received: 07.11.2020 | Accepted: 16.11.2020 | Published: 30.11.2020

*Corresponding author: Sean D. Yates

Abstract

This article discusses legal pluralism and how conflicts are managed when multiple systems operate on given events. It sheds light on the case of Meng Wanzhou, Huawei's CFO, in Vancouver, Canada, who is currently facing extradition proceedings to the United States. The case sheds light on issues that can arise where legal systems overlap, in this case, those of the Royal Canadian Mounted Police (RCMP) and the Canadian Border Services Agency (CBSA), which have distinct mandates and operate under a separate legislative authority. It tackles how they are jointly involved in Ms Meng's detention, interrogation and ultimate arrest and the need for an independent oversight of the CBSA which remains the only policing service within Canada that does not have some form of independent oversight body.

Keywords: legal pluralism, Canadian Border Services Agency (CBSA), legal systems overlap.

Copyright $\odot$ 2020 The Author(s): This is an open-access article distributed under the terms of the Creative Commons Attribution 4.0 International License (CC BY-NC 4.0) which permits unrestricted use, distribution, and reproduction in any medium for non-commercial use provided the original author and source are credited.

\section{INTRODUCTION}

This article considers legal pluralism, the understanding that our lives are simultaneously governed by multiple systems of rules, and how, when more than one system operates on given events, conflicts are managed. As a current and topical case study, it looks at the case of Meng Wanzhou, Huawei's CFO, in Vancouver, Canada, who currently faces extradition proceedings to the United States. The case highlights issues that can arise where legal systems overlap, in this case, those of the Royal Canadian Mounted Police (RCMP) and the Canadian Border Services Agency (CBSA), which have distinct mandates and operate under separate legislative authority. It considers their joint and coordinated involvement in Ms Meng's detention, interrogation and ultimate arrest and the need for independent oversight of the CBSA which remains the only policing service within Canada not to have some form of independent oversight body.

The first part briefly outlines the general concept of legal pluralism before looking at policing pluralisation in particular. It develops the idea of collusive-conflict risk where different legal orders overlap and simultaneously impact on a given context. The second section discusses interrogation and recognised differences between admission-seeking and intelligence-seeking paradigms. It suggests their incompatibility and non-transferable nature due to differing ideologies. The third section considers independent oversight as a mechanism through which pluralist collusive-conflict risks might be managed, with particular reference to the CBSA. The fourth section briefly analyses some issues arising in Meng's case as being symptomatic of unmanaged collusiveconflict risk leading to increased potential for abuse of process and circumvention of Charter rights. This has led to a significant concern in Meng's case that the RCMP has effectively used the CBSA as a conduit or proxy through which to conduct interrogation and gather evidence which the RCMP itself could not have.

\section{Legal Pluralism}

Legal pluralism acknowledges that at any given time, we are subject to a multiplicity of legal orders, rules and obligations, all of which govern our behaviour and daily lives [1]. These include statecreated law, international law, and non-state law such as religious laws, social conventions, and even the rules of a university, social club or gym. It also extends to licence agreements made with software providers, warranty agreements for purchased goods and rules relating to the premises in which we live and work.

1 Twining, W. I. (2009). "Normative and legal pluralism: a global perspective." Duke J. Comp. \& Int'1 L. 20: 473. 
These obligations can overlap and simultaneously operate on the same set of circumstances. The requirement to pay for a restaurant meal may for instance stem from state law while religion may dictate what you may eat, social custom how you eat it, and the restaurant dress code the attire you can wear. At an international macro level, there are overlaps between European law and that of member States, between the role of the International Criminal Court and national criminal legislation obligations. The interplay of obligations mostly run in parallel, but not always consistently.

It is also possible for more than one system of State law to impact, such as federal and state-level law, criminal and civil law, private and public law and, in common law systems, law and equity. Where there is a conflict as to jurisdiction, two systems claiming the right to make a determination (positive conflict), or alternatively each denying it is they who must make it (negative conflict), it is not uncommon for a separate body to be established to determine where the correct jurisdiction lies [2].

The overlap of jurisdiction or interaction between legal systems must therefore be addressed, either to determine which set of norms prevails or alternatively to preserve the plurality. Absent a specialised tribunal, this is more typically achieved by procedural mechanisms, institutions and practices, which according to Berman can never definitively or satisfactorily resolve an issue, because 'there is at a root level no way to "solve" problems of pluralism' [3]. The issue then is one of management of the opposing effects from different systems. Berman identifies and illustrates examples of eight such mechanisms, at the same time accepting these may be considered to deliver unsatisfactory compromises. Yet, as Berman rightly emphasises, the mere recognition of the importance of mechanisms to manage conflicts arising from pluralism is a crucial first step [4].

The space in which different legal systems overlap may also, I suggest, experience a different form of conflict, not oppositional but collusion-enabling, whereby elements are co-opted across different systems to achieve outcomes that would otherwise be proscribed. This collusion-enabling conflict that I will

2 In France, which has separate courts for public and private law matters, the highest court for each being respectively the Conseil d'Etat and Cour de Cassation, where there is a conflict as to which has jurisdiction, the Tribunal des conflits makes the determination <<http://www.tribunal-des-conflits.fr/>>.

3 Berman, P. S. (2012). Global legal pluralism: A jurisprudence of law beyond borders, Cambridge University Press. term 'collusive-conflict', which gives rise to an undesirable outcome antithetical to either system's normative mandate is not, I suggest, dealt with by Berman's managing mechanisms, which address the traditional oppositional conflict. However, his point that identification of relevant managing mechanisms as a crucial first step remains relevant, and it is in this context I suggest the importance of independent oversight, as an additional mechanism through which to mitigate the risks associated with collusive-conflict.

\section{Pluralised Policing}

Pluralised policing involves entities other than state police sharing responsibility for safety and other policing responsibilities [5]. The diversity of policing provision must however preserve 'sustained legitimacy, skilled professionalism and effective accountability' to retain its democratic character [6]. A failure to enforce law neutrally and without discrimination or bias will undermine legitimacy [7]. Governance and accountability of state police is typically regulated, aimed at ensuring recruitment standards, appropriate training and complaints procedures. Effective regulation methods, as Walsh and Conway argue, have their own objectives, which may include:

legitimacy, the maintenance of democratic values, the protection of human rights, transparency, the promotion of force efficiency and discipline and the enhancement of police community relations which, in turn, can improve the capacity of police bodies to discharge their functions [8].

Where different standards apply as between policing bodies, parallel systems and therefore inconsistent outcomes can arise. Differing standards may apply to separate arms of the State essentially performing the same or similar tasks, for example, a traffic warden or a police officer administering tickets for a parking violation. Collusion-conflict in the pluralist policing context risks the legitimacy of both systems, which accounts for Walsh and Conway's identification of policing as a highly regulated area. Regulation must additionally avoid insularity, as failing to acknowledge collusive-conflict potential may be

5Stenning, P. (2009). "Governance and accountability in a plural policing environment-The story so far." Policing: a journal of policy and practice $3(1)$ : 22-33. 6 Lobnikar, B., et al. (2015). Do we trust them? Public opinion on police work in plural policing environments in Central and Eastern Europe. Trust and Legitimacy in Criminal Justice, Springer: 189-202.

7 Caparini, M. and O. Marenin (2004). "Transforming Police in Central and Eastern Europe." Process and Progress, Münster.

8 Walsh, D. P. and V. Conway (2011). "Police governance and accountability: overview of current issues." Crime, law and social change 55(2-3): 61-86. 
more likely where there is self-governance. Training that includes lessons borne out of documented collusion-conflict incidents, and measured through appropriate feedback from independent oversight, is more likely to provide effective management.

\section{Interrogation}

CBSA and RCMP interrogation powers are different. The Customs Act gives CBSA officers powers to seize goods and to detain, question, search and examine individuals that would be unconstitutional if carried out against persons already in Canada [9]. It is also an offence for persons looking to enter Canada not to answer truthfully questions posed by a CBSA officer. There is therefore a compulsion to provide evidence which may be self-incriminating [10]. Canada's Charter ensures this is not the standard applied to those interrogated by the RCMP inside Canada.

Importantly, CBSA and RCMP interrogation aims are also different. We might distinguish between coercive interrogation seeking to corroborate suspected facts already ascertained, and fact-finding investigative interrogation. The CBSA's role is more investigative given that at the start of an interrogation, officers will often not know what they are looking for and are more reliant on the ongoing information they receive from a detainee for the questions they subsequently ask. The obligation on those questioned by the CBSA to answer and to answer truthfully may arise out of this factor, reflecting that where an interrogation is primarily investigative, information obtained is not immediately corroborable. By contrast, in coercive interrogation, the interrogator is usually aware of the circumstances surrounding the alleged offence and so can more easily respond to false or evasive answers from a suspect.

RCMP and CBSA interrogations are therefore qualitatively different, not just distinguishable by jurisdiction and Charter rights applicability. CBSA investigative interrogation lends itself to searching for evidence of unidentified potential crimes. In contrast, Charter rights against self-incrimination would preclude RCMP coercive interrogation from being used solely for such purpose. This qualitative difference potentially further aggravates CBSA and RCMP collusion-conflict incidents, especially where there are allegations, as in Meng's case, that CBSA interrogation has deliberately been used to search for information relating to unknown offences [11].

Different jurisdictions take different approaches to the control of interrogation practices. In England and Australia, police investigations are

9 Section 99(1) Customs Act; Sections 15, 16 and 18 Immigration and Refugee Protection Act.

10 R. v. Singh, 2019 ONCJ 453 para. 64.

11 In this case at the behest of a foreign agent, the United States' Federal Bureau of Investigation. regulated by legislation, whereas in the United States, after the event judicial decisions provide oversight. Likewise, judges control evidence admissibility, including confessions. Dixon suggests that:

[S]tandard U.S. practices such as lying to a suspect that incriminating physical evidence has been found should lead to exclusion by Anglo-Australian judges of a subsequent confession [12].

Dixon also points to the important distinction between interrogation intended to produce confessions and admissions acceptable to a criminal justice paradigm, the purview of the RCMP, and that obtained for intelligence purposes, often undertaken by state intelligence representatives rather than state police. In Meng's case, CBSA's questioning was not aimed at securing an arrest - this was already going to happen but rather at intelligence gathering.

These two interrogative processes, or paradigms, are antithetical. For instance

If an interrogator does not anticipate the requirements for successful presentation, examination, and admission to evidence of interrogation in court, problems arise when attempts are made to cross paradigms [13].

It can also cause problems for authorities seeking to use any material for evidential purposes that was collected for intelligence purposes. For example, lengthy pre-trial detention may undermine the voluntariness necessary for information to be admitted into evidence [14]. It is therefore critical that these different interrogation paradigms be recognized and their separate deployment be preserved.

As outlined in the introduction, a significant concern in Meng's case is therefore that the RCMP has effectively used the CBSA as a conduit or proxy through which to perform interrogation and evidence gathering which the RCMP could not itself have performed. This is due to the different rules applicable to the CBSA, but also because of the different paradigms in which they operate.

\section{CBSA and Independent Oversight}

The CBSA remains the only policing service within Canada not to have some form of independent oversight body [15]. Despite decades of lobbying by interest groups for such accountability, the CBSA

\section{Ibid.}

14 Ibid.

15 < <https://www.cbc.ca/news/politics/cbsa-refugeeimmigrant-detention-oversight-1.3515087>>.

Complaints of on-duty improper conduct against RCMP members are by contrast overseen by the Civilian Review and Complaints Commission. 
continues to handle public complaints internally [16]. Further, and critically, where problems are identified and corrective measures are taken, details are not made public.

In January 2020, the Privacy Commissioner found that several CBSA officers had contravened federal law by unduly searching personal electronic devices of persons crossing the border and who had complained about CBSA activities [17]. A bill is currently before the Canadian Parliament to bring the CBSA under the same oversight as the RCMP, the Public Complaints and Review Commission (PCRC) [18].

The CBSA has also been subject to judicial criticism. Section 163.5 (4) of the Customs Act explicitly limits the CBSA's powers to gathering evidence to support Customs Act offences:

A designated officer may not use any power conferred on the officer for the enforcement of the Act for the sole purpose of looking for evidence of a criminal offence under any other Act of Parliament.

In $R v$ Brode [19] Justice Epstein reiterated this:

"there is a limitation on these powers: a designated BSO may not use any power conferred for the enforcement of the Customs Act for the sole purpose of looking for evidence of a criminal offence under any other Act of Parliament [20]".

In $R v$ Singh, Justice E. Deluzio found CBSA Officers had systematically acted as agents of the police,

conducting searches of cell phones and other devices for the sole purpose of gathering evidence to support criminal code charges and criminal code prosecutions [21].

The judge ultimately excluded evidence obtained by the CBSA, ruling as follows:

After balancing all of the Grant factors and considerations, and in particular the systemic state conduct involving Border Officers, routinely relying on search powers conferred upon them by the Customs Act and IRPA for the sole purpose of Criminal

$16<<$ https://www.bellissimolawgroup.com/oversightof-the-cbsa-is-a-watchdog-forthcoming/>>.

18 Casavant, L. and D. Valiquet (2010). Bill C-38: An Act to amend the Royal Canadian Mounted Police Act and to make consequential amendments to other Acts, Library of Parliament; <<https://www.canada.ca/en/public-safetycanada/news/2020/01/bill-c-3-independent-review-ofthe-canada-border-services-agency.html >>.

19 R v Brode [2012] O.J. No 985.
Code...investigations, it is my view that admission of the evidence...would bring the administration of justice into disrepute [22].

In isolation, judicial correction of abuses arising out of collusive-conflict contexts, by disallowing confessions or excluding evidence, is not a panacea, for at least two reasons. First, it is likely to operate only in extreme cases without addressing unreported abuses or those which for reasons other than merit received no judicial determination. Secondly, corrective action only against those matters which reach the court process may not capture lower level instances of collusive-conflict abuse which are more widespread and are therefore more likely to result in normative entrenchment. As with judicial control over the admissibility of confessions and admissions, this is an exercise of court process regulation and only indirectly affects police behavior [23]. Effective regulation must operate closer to the source.

An independent oversight body akin to that to which RCMP is subject may operate more effectively to identify the prevalence as well as the degree of severity of collusive-conflict abuses. A further benefit is such a body's ability to determine whether a problem is symptomatic of individual or localised instances or has become systemic. In terms of data, complaints to an overseeing body will outnumber incidents that result in court cases and may better support proposals for reform and targeted re-education.

Oversight can also make better use of complaints deemed substantively unmeritorious but which may still translate into more nuanced improvements in areas such as attitude, ideology and customer service-level benchmarking. Under the draft Bill, service standards would be set jointly by CBSA and PCRC, which would legitimise the metrics by which performance is gaged and also increase CBSA buy-in. The draft Bill also mandates the PCRC to educate and raise awareness of its role among those who come into contact with the CBSA, including those who are detained, ${ }^{24}$ an important directive raising oversight efficacy. The proposal significantly improves upon the current CBSA system of self-regulated private oversight according to self-set standards.

22 R. v. Singh, 2019 ONCJ 453 para. 102.

23 Dixon, D. (2017). "Interrogation law and practice in common law jurisdictions." The Oxford Handbook of Criminal Process: 17-55.

24 Casavant, L. and D. Valiquet (2010). Bill C-38: An Act to amend the Royal Canadian Mounted Police Act and to make consequential amendments to other Acts, Library of Parliament. 


\section{Meng's Case}

The facts of Meng's case giving rise to her legal defence of abuse of process involve her arrival at Vancouver International Airport, and subsequent detention and interrogation by CBSA officers until her arrest by RCMP officers some three hours later. From a collusive-conflict risk perspective, several elements of Meng's processing, which largely constitute the basis of her complaint, signal a blending by the two agencies, pooling their respective powers to achieve a sum exceeding their individual parts. These include the following:

A. RCMP had obtained an arrest warrant, requiring that Meng be arrested 'immediately'. Upon execution, Meng would have to be told the reason for her arrest and of her entitlement to legal representation. An initial plan to arrest her on the plane was changed. Instead of being arrested immediately, she was detained and interrogated by CBSA officers for three hours, ostensibly for a routine examination under CBSA's powers, which did not require her to be advised of the reasons for her detention or give her entitlement to legal representation [25].

B. Meng was compelled to provide digital devices in her possession along with access codes. CBSA could require both, RCMP could not have done without a further court order and justification. CBSA passed both the devices and the access codes to RCMP when Meng was eventually arrested by RCMP. They should not have provided the access codes. CBSA says this was a mistake on their part.

C. During their interrogation, CBSA officers asked Meng about matters related to charges against her in the United States contained in the warrant behind the extradition request. Specifically, she was asked about Huawei's business dealings in Iran. RCMP could not have asked such questions without having first arrested Meng, advising of the reasons for her arrest and her right to legal representation [26].

Additional questions have been raised concerning CBSA and RCMP evidence, but these are not immediately identifiable as being of a collusiveconflict nature. The suspected mischief in the fact patterns outlined above is that collusion between the RCMP and CBSA was used to circumvent Charter rights, to facilitate interrogation and search, without legal advice, in an attempt to obtain factual and physical evidence which might not, by virtue of the law, have otherwise been obtainable had the RCMP arrested Meng immediately. I suggest it is an aggravating factor that CBSA interrogation is qualitatively different and that it was used to question about Huawei's activities in Iran, the subject of the foreign arrest warrant, and not part of the CBSA's standard passenger screening process.

To close the loop, we know from contemporaneous notes in Meng's case that the intention was for information obtained by the CBSA to be shared with the RCMP. An RCMP officer's note from a meeting just hours before Meng's arrival, when it was decided not to arrest her immediately, but instead to allow CBSA officers first to conduct an interrogation, states:

-educated about process of CBSA in dealing with foreign national, exam by CBSA required. Info obtained later by sec 107 request [27].

Section 107 of the Customs Act referred to allows for information compelled from travellers to be shared with other law enforcement bodies. The shared information should, of course, be that obtained independently by the supplying body in the exercise of its own duties; the section 107 mechanism does not serve or operate to legitimise information passing between separate bodies that has been illegitimately obtained.

Whether the authorities' actions are otherwise explicable will be determined by the court, but determination at this level is unlikely to deter or reduce a systemic problem. In Meng's case, a stay of her case if abuse of process is established would vindicate the complaint against her own treatment, but as they stand, the facts alone again signal the need for additional oversight and accountability in an area of law were collusive-conflict related abuses continue to occur.

\section{CONCLUSION}

This paper has sought to establish that a legal pluralist analysis of coexisting legal orders identifies their overlapping application and the potential for inconsistent outcomes. Such conflicts can be and are commonly managed. The potential for collusionconflict, where standards from one order are co-opted by another order, are less commonly explored. Pluralist policing raises particular issues of legitimacy and accountability, especially where features of different interrogation paradigms are grafted between processes.

Collusion-conflict risks must likewise be managed, and one mechanism is independent oversight. The CBSA does not currently have the benefit of independent oversight and should be brought under the same or similar regime to that of the RCMP. Both bodies should be subject to independent oversight for

27 Note of RCMP Ross Lundie, December 1, 2018 ,

evidence in proceedings.
25 Immigration and Refugee Protection Act, S.C. 2001, c. 27('IRPA"); Customs Act, R.S.C. 1985, c. 1.

26 Under Sections 10(a) and (b) of the Charter. 
collusion-conflict risks to be managed and the potential for abuse reduced.

Effective collusion-conflict risk management can avoid courts having to determine the types of issues that have arisen in Meng's case over what must be at best mistakes and at worst, examples of intentional collusive-conflict enabled behaviour amounting to an abuse of process and of Ms Meng's rights.

What remains unsatisfactory is Ms Meng potentially paying the price for overdue independent oversight of the CBSA which has a high likelihood of averting these conflicts and their unwelcome results. 